\title{
Changes in the physicochemical and microbiological properties of frozen araça pulp during storage
}

\author{
Alterações físico-químicas e microbiológicas de polpa congelada de araçá durante a estocagem
}

Clarissa DAMIANI ${ }^{1 \star}$, Moacir Evandro LAGE², Flávio Alves da SILVA ${ }^{1}$, Douglas Endrigo Perez PEREIRA³ Fernanda Salamoni BECKER ${ }^{4}$, Eduardo Valério de Barros VILAS BOAS ${ }^{4}$

\begin{abstract}
Araça belongs to the Myrtaceae family and is popularly known as araçá-comum, araçá-azedo, or araçá-do-campo. Frozen fruit pulp is of great importance for the food industry, which can produce it at the time of harvest, store it, and use it according to the demand of the consumer market and/or as an ingredient in the formulation of products such as yogurt, candies, and ice creams among others. The aim of this study was to evaluate the physical, chemical, and microbiological stability of frozen araça pulp during 12 months of frozen storage. It was observed that the levels of moisture (90.55-88.75\%), ash (0.34-0.26\%) total soluble sugars (7.11-6.62\%), sucrose (3.55-1.39\%), soluble pectin (0.24-0.23\%), total pectin (0.5-0.46\%), $\mathrm{pH}(3.82-2.31 \%)$, organic acids (698.12-122.25 $\mu \mathrm{g} \cdot \mathrm{g}^{-1}$ citric acid), and phenolic compounds (6.22-0.00 mg GAE.100 $\left.\mathrm{g}^{-1}\right)$ decreased during storage, whereas the levels of protein (0.61-0.83\%), lipids (0.14- $\left.0.38 \%\right)$, total carbohydrates (8.36-9.78\%), calorific value (37.14-45.86 kcal.100 $\left.\mathrm{g}^{-1}\right)$, reducing sugars (3.51-5.21\%), soluble solids (5.17-6.0\%), total antioxidant capacity (6.89-35.13\%), and color parameters ( $\mathrm{L}^{\star} 49.75-50.67 ; \mathrm{a}^{\star} 0.79-1.82$ and $\left.\mathrm{b}^{\star} 22.5-25.19\right)$ increased over the one-year storage period. According to the chemical and microbiological parameters assessed, the product can be stored for 12 months without loss of quality with addition of citric acid as a preservative.
\end{abstract}

Keywords: savanna fruits; Psidium Guineans Sw; shelf-life.

\section{Resumo}

O araçá pertence à família Myrtaceae, sendo conhecido popularmente como araçá-comum, araçá-azedo ou araçá-do-campo. Polpas de frutas congeladas têm grande importância para a indústria de alimentos, que podem produzi-las na época de safra, armazená-las e utilizá-las conforme a demanda do mercado consumidor e/ou como parte da formulação de produtos como iogurtes, doces, gelados comestíveis, entre outros. Objetivou-se avaliar a estabilidade física, química e microbiológica de polpa de araçá durante o período de 12 meses de armazenamento sob congelamento. Observou-se que os teores de umidade (90,55-88,75\%), cinzas (0,34-0,26\%), açúcares solúveis totais (7,11-6,62\%), sacarose (3,55-1,39\%), pectina solúvel (0,24-0,23\%), pectina total (0,5-0,46\%), pH (3,82-2,31\%), ácidos orgânicos (698,12-122,25 $\mu$ g.g-1 de ácido cítrico) e compostos fenólicos $\left(6,22-0,00\right.$ mgEAG. $\left.100 \mathrm{~g}^{-1}\right)$ tiveram seus teores reduzidos ao longo do armazenamento; enquanto que proteína (0,610,83\%), lipídios (0,14-0,38\%), carboidratos totais (8,36-9,78\%), valor calórico (37,14-45,86 kcal.100 g-1), açúcares redutores $(3,51-5,21 \%)$, sólidos solúveis $(5,17-6,0 \%)$, potencial antioxidante total $(6,89-35,13 \%)$ e parâmetros de cor $\left(L^{\star} 49,75-50,67 ; a^{\star} 0,79-1,82\right.$ e b²2,5-25,19) apresentaram ascensão durante 1 ano de estocagem. De acordo com os parâmetros analisados (químicos e microbiológicos), o produto pode ser armazenado por 12 meses, sem prejuízo em sua qualidade, com adição de ácido cítrico como conservante.

Palavras-chave: frutos do Cerrado; Psidium Guineenses Sw.; vida-útil.

\section{Introduction}

The Brazilian Savanna has a large number of edible fruits that have been consumed by human populations since ancient times. These native fruits are consumed both raw and in the form of sweet desserts, cakes, breads, cookies, jams, and liqueurs (ALMEIDA, 1998). Among these species, Araça stands out; it is a fruit native to Brazil that belongs to the Myrtaceae family and is found from the state of Rio Grande do Sul in southern Brazil, Minas Gerais in southeastern Brazil, up to the Amazon region, where many native species are grown and show excellent production (MANICA, 2000).

Psidium guineensis Sw. is a small bush, and its fruit is known by many different names in Brazil, such as araça, araçaí, araçado-campo, araça-mirim, goiaba-da-guiné, or araça-azedo. This fruit, which can be eaten raw or in the form of desserts, drinks, ice cream, and liqueur, is a spherical globular berry, 1.5 to 4.5 in $\mathrm{cm}$ diameter, whose skin goes from whitish-yellow, greenishyellow, and pale yellow to yellow when ripe.

The araça pulp is fleshy, white, mucilaginous, sweet, slightly tart, aromatic, and it has numerous small seeds (MANICA,

Received 12/7/2012

Accepted 14/9/2012 (00Q5786)

${ }^{1}$ Department of Food Engineering, School of Agronomy and Food Engineering, Federal University of Goias - UFG, Rod. Goiânia, Km 0, Nova Veneza, CEP 74001-970,

Goiânia, GO, Brazil, e-mail: damianiclarissa@hotmail.com

2 School of Veterinary, Federal University of Goias - UFG, Rod. Goiânia, Km 0, Nova Veneza, CEP 74001-970, Goiânia, GO, Brazil

${ }^{3}$ Laboratory of Food Chemistry and Biochemistry, School of Pharmacy, Federal University of Goias - UFG, Praça Universitária, 1a, Av. Laboratório de Química de Alimentos,

Setor Universitário, CEP 74605-220, Goiânia, GO, Brazil

${ }^{4}$ Department of Food Science, Federal University of Lavras - UFLA, CP 37, CEP 37200-000, Lavras, MG, Brazil

${ }^{*}$ Corresponding author 
2000). The fruit contains $89.91 \%$ water, $0.80 \%$ ash, $1.54 \%$ malic acid, 5.54\% sugars, $2.55 \%$ cellulose, and $0.20 \%$ fat (MANICA, 2000). Franco (1999) found $48 \mu \mathrm{g}$ retinol, $60 \mu \mathrm{g}$ thiamin, $40 \mu \mathrm{g}$ riboflavin, $1.3 \mathrm{mg}$ niacin, $326 \mathrm{mg}$ ascorbic acid, $8 \mathrm{~g}$ sugars, $1 \mathrm{~g}$ protein, $0.2 \mathrm{~g}$ lipids, $14 \mathrm{mg}$ calcium, $30 \mathrm{mg}$ phosphorus, $1.05 \mathrm{mg}$ iron, and $37.8 \mathrm{kcal}$ in $100 \mathrm{~g}$ of fruit.

Although araça has been consumed for many years, only few people have access to this fruit since it is only found in some regions of the country, and it is available a few months a year. To solve this problem, food technology can add value to these fruits by ensuring their consumption throughout the entire year and making them available all over the country.

With the technology available, the market for frozen fruit pulp has shown reasonable growth and great market potential due to the variety of fruits with nice exotic tastes (BUENO et al., 2002; SILVA et al., 2010). The aim of the freezing process is to preserve food stored for long periods. However, changes can occur even at temperatures below $0{ }^{\circ} \mathrm{C}$. The speed at which foods have been frozen and the temperature stability during storage are factors that contribute to their stability (AGOSTINICOSTA; ABREU; ROSSETTI, 2003; YAMASHITA et al., 2003; SILVA et al., 2010).

Therefore, the aim of this study was to use araça fruit to make araça pulp and to evaluate the pulp chemical, physical, and microbiological stability during storage $\left(-18^{\circ} \mathrm{C}\right)$.

\section{Materials and methods}

Araça fruits harvested in 2010 in the State of Minas Gerais, Brazil were used. After selection, the fruits were washed to remove surface contamination, rinsed, and submerged in a 100. $\mu 1 . \mathrm{L}^{-1}$ sodium hypochlorite solution for 20 minutes.

The fruits $(20 \mathrm{~kg})$ were then pulped using a depulper (Bonina, Model 0.25 DF, Itabuna, Brazil); the pulp obtained $(18.6 \mathrm{~kg})$ was added with citric acid $(1 \%)$, pasteurized $\left(95^{\circ} \mathrm{C} / 5\right.$ minutes $)$, hot packed $\left(85^{\circ} \mathrm{C}\right)$ in $12 \times 26 \mathrm{~cm}$ low-density polyethylene (LDPE) bags of $0.20 \mathrm{~mm}$ thickness and capacity of $100 \mathrm{~g}$, cooled in an ice bath, and stored at $-18^{\circ} \mathrm{C}$ in a domestic freezer (Electrolux, Model H400, Curitiba, Brazil) for analysis of stability for 12 months. Pulp samples were thawed in the package after $0,2,4,6,8,10$, and 12 months of storage by immersion in a water bath at $25^{\circ} \mathrm{C}$ for 6 minutes and evaluated for physical, chemical, and microbiological characteristics, namely: moisture, ash, protein, lipids, total carbohydrates, caloric value, total sugars, reducing sugars, sucrose, soluble solids, total pectin, soluble pectin, antioxidant compounds, phenolics, $\mathrm{pH}$, organic acids, color $\left(\mathrm{L}^{*}, \mathrm{a}^{*}, \mathrm{~b}^{*}\right)$, and filamentous fungi and yeasts, coliforms at 35 and $45^{\circ} \mathrm{C}$, and Salmonella sp. The analyses were carried out in triplicate.

Moisture $\left(105^{\circ} \mathrm{C}\right)$, ash (incineration at $550{ }^{\circ} \mathrm{C}$ ), protein $(\mathrm{N} \times 0.65)$, lipids, $\mathrm{pH}$, soluble solids, soluble sugars, sugars, and sucrose contents were determined according to the Association of Official Analytical Chemists - AOAC (ASSOCIATION..., 1997), and the results were expressed as percentages. Total and soluble pectin contents were determined by the colorimetric method according to Bitter and Muir (1962); the total carbohydrate content was determined according to Dubois et al. (1956), and the total caloric value was estimated as the Atwater conversion factors according to Wilson, Santos and Vieira (1982); the results were expressed as percentage and kcal, respectively.

Organic acids were extracted according to Bazimarakenga, Simard and Leurox (1995), modified by Silva et al. (2001), and the identification and quantification of citric, malic, tartaric, and ascorbic acids were performed by HPLC (High Performance Liquid Chromatography) using a Shimadzu model CLASS LC 10 chromatograph, (Kyoto, Japan) equipped with SPD-M10A UV detector, at wavelength of $230 \mathrm{~nm}$, using a $\mathrm{C}-18$ reverse phase column $(150 \times 4.6 \mathrm{~mm} \mathrm{ID}, 3 \mu \mathrm{m})$. The sample injection volume was adjusted to $20 \mu \mathrm{L}$ using water containing $0.1 \%$ phosphoric acid as the mobile phase at flow rate of $1 \mathrm{~mL} \cdot \mathrm{min}^{-1}$. Identification was based on retention times and co-chromatography absorption spectra whenever necessary. Quantification was performed based on a seven point external calibration curve for each organic acid. The following concentrations were used to draw the standard curve: $0.8,0.5$, 0.25 and $0.01 \mathrm{mg} \cdot \mathrm{mL}^{-1}$ for citric, malic, tartaric and ascorbic acid, respectively; the other six points were obtained by dilution in series with mobile phase (1/1). Calibration curves were also used to evaluate the linearity range. All samples including the mobile phase were filtered through a micron membrane filter (0.45 micron pore (Millipore JBR61022 and HAWP04700). The results were expressed as $\mu \mathrm{g} \cdot \mathrm{g}^{-1}$.

The antioxidant capacity was determined by the DPPH method as described by Brand-Williams, Cuvelier and Berset (1995) and modified by Borguini and Torres (2009). The discoloration degree of the DPPH radical at $517 \mathrm{~nm}$ by the action of antioxidants was measured in the ethereal, alcoholic, and aqueous extracts with concentration of $0.2 \mathrm{mg} \cdot \mathrm{mL}^{-1}$ using a spectrophotometer (Shimadzu, model UV-1601 PC, Kyoto, Japão), and the results expressed as \% DPPH discoloration. Extractions were performed in triplicate for each sample. Ethereal, alcoholic, and aqueous extracts were obtained from frozen samples using a sequential extraction process for fruits (BORGUINI; TORRES, 2009).

The extraction of alcoholic and aqueous compounds was carried out as described by Genovese et al. (2003) for determination of phenolic compounds using Folin-Ciocalteu reagent. The determination of these phenols was described by Zieliski and Kozowaska (2000), and the results were expressed as mg GAE. $100 \mathrm{~g}^{-1}$.

Color was determined using a Konica Minolta CR-400 colorimeter (Manaus, Brazil) according to the CIE system, measuring $\mathrm{L}^{*}, \mathrm{a}^{\star}$ and $\mathrm{b}^{*}$ (observation angle of $10^{\circ}$ and illuminant D65). The $\mathrm{L}^{\star}$ coordinate represents the lightness/darkness of the pulp, with values ranging from 0 (totally black) to 100 (totally white); $\mathrm{a}^{*}$ coordinate shows values between -80 and +100 , and the extremes correspond to green and red, respectively; and $b^{*}$ coordinate shows values ranging from -50 to +70 , with intensity from blue to yellow. The readings were made at three distinct points in each pulp package. 
The microbiological analyses for filamentous fungi and yeasts, coliforms at 35 and $45^{\circ} \mathrm{C}$, and Salmonella sp. followed the methodology proposed by the International Commission on Microbiological Specifications for Foods - ICMSF (INTERNATIONAL..., 1983).

A completely randomized design (CRD) was used, and the influence of seven levels of factor time was evaluated $(0,2,4,6$, 8,10 , and 12 months). Each experimental plot consisted of five packages containing $100 \mathrm{~g}$ of pulp with three replicates each.

The statistical analysis was performed using the SISVAR software (FERREIRA, 2000). After applying the analysis of variance, at significance level of $5 \%(\mathrm{p}<0.05)$, polynomial
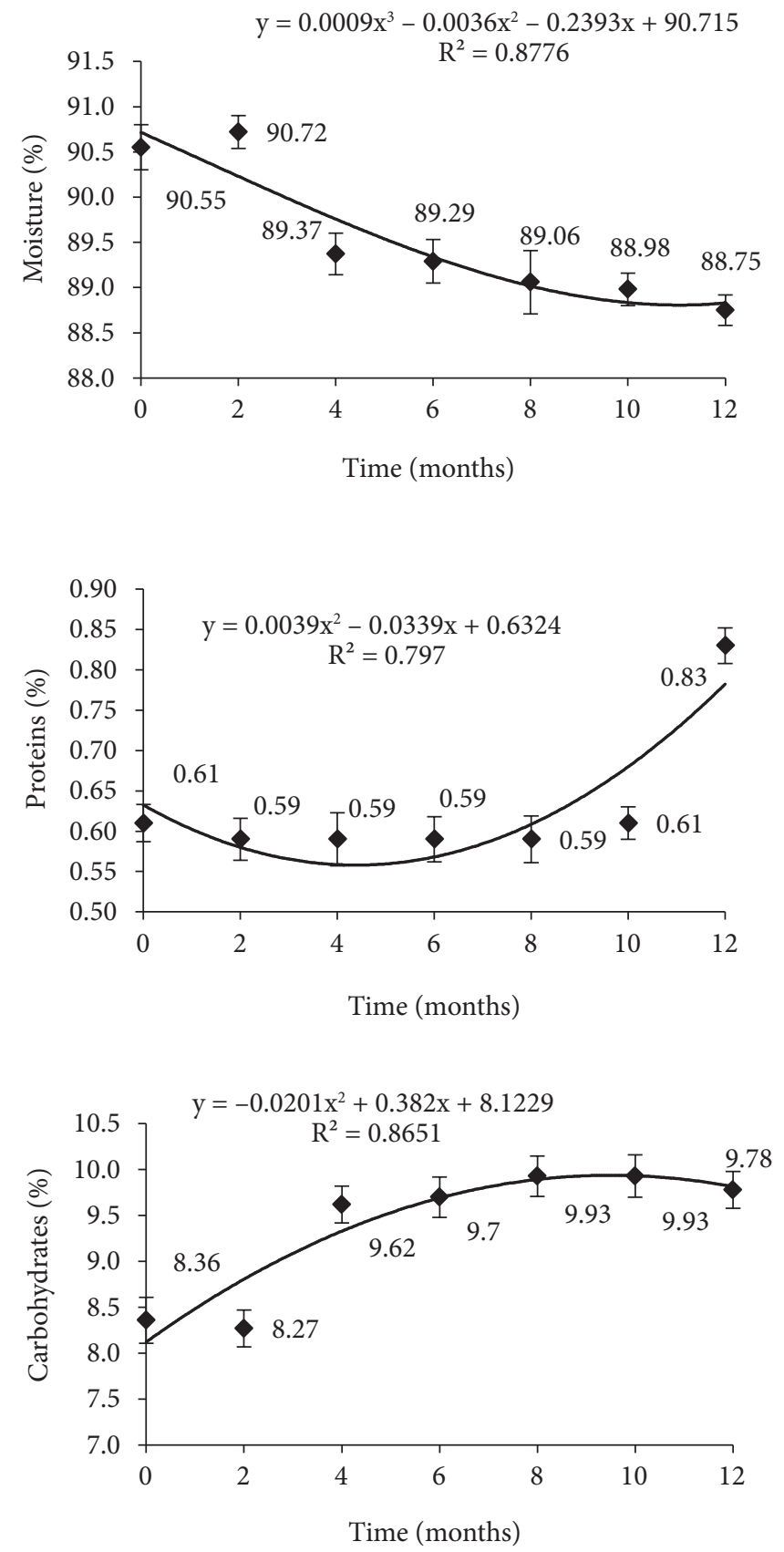

regression models were selected based on the significance of the $\mathrm{F}$ test for each model tested and also by the determination coefficient.

\section{Results and discussion}

Figure 1 shows the results obtained in the proximate analysis of the araça frozen pulp.

Moisture, protein, fat, total carbohydrate content, ash, and caloric value were influenced by the factor time $(\mathrm{p}<0.05)$. With the reduction in moisture content (1.98\%), the other components tended to increase since, according to Cheftel,
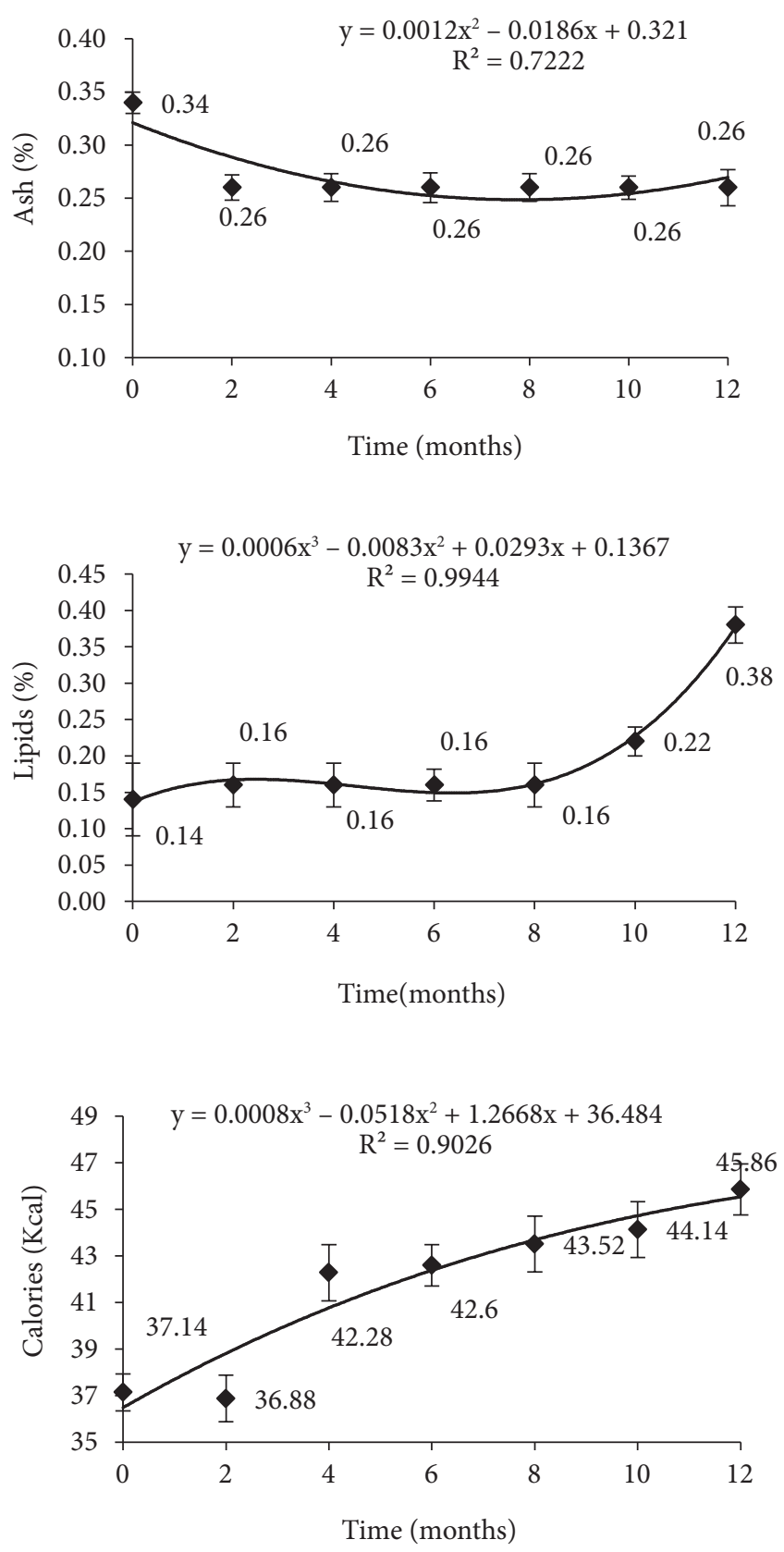

Figure 1. Proximal composition (wet basis) of frozen araça pulp $\left(-18^{\circ} \mathrm{C}\right)$ during 12 months of storage. 
Cheftel and Besançon (1989), in an aqueous solution at $-18^{\circ} \mathrm{C}$, part of the water remains in the liquid state and can evaporate into the air through the package, thus reducing its content in the frozen product. Silva, Santos Júnior and Ferreira (2008) also observed a reduction in moisture content during storage $\left(-18^{\circ} \mathrm{C} / 4\right.$ months $)$ in frozen cagaita pulp.

A factor that considers changes in the chemical constituents of the araça pulp is the freezing process because although the effect of temperature is the reduction of reaction rates, the overall reaction rate can increase or decrease less than expected as a result of the higher reactant concentrations that result from freeze concentration (DAMODARAN; PARKIN; FENNEMA, 2010).
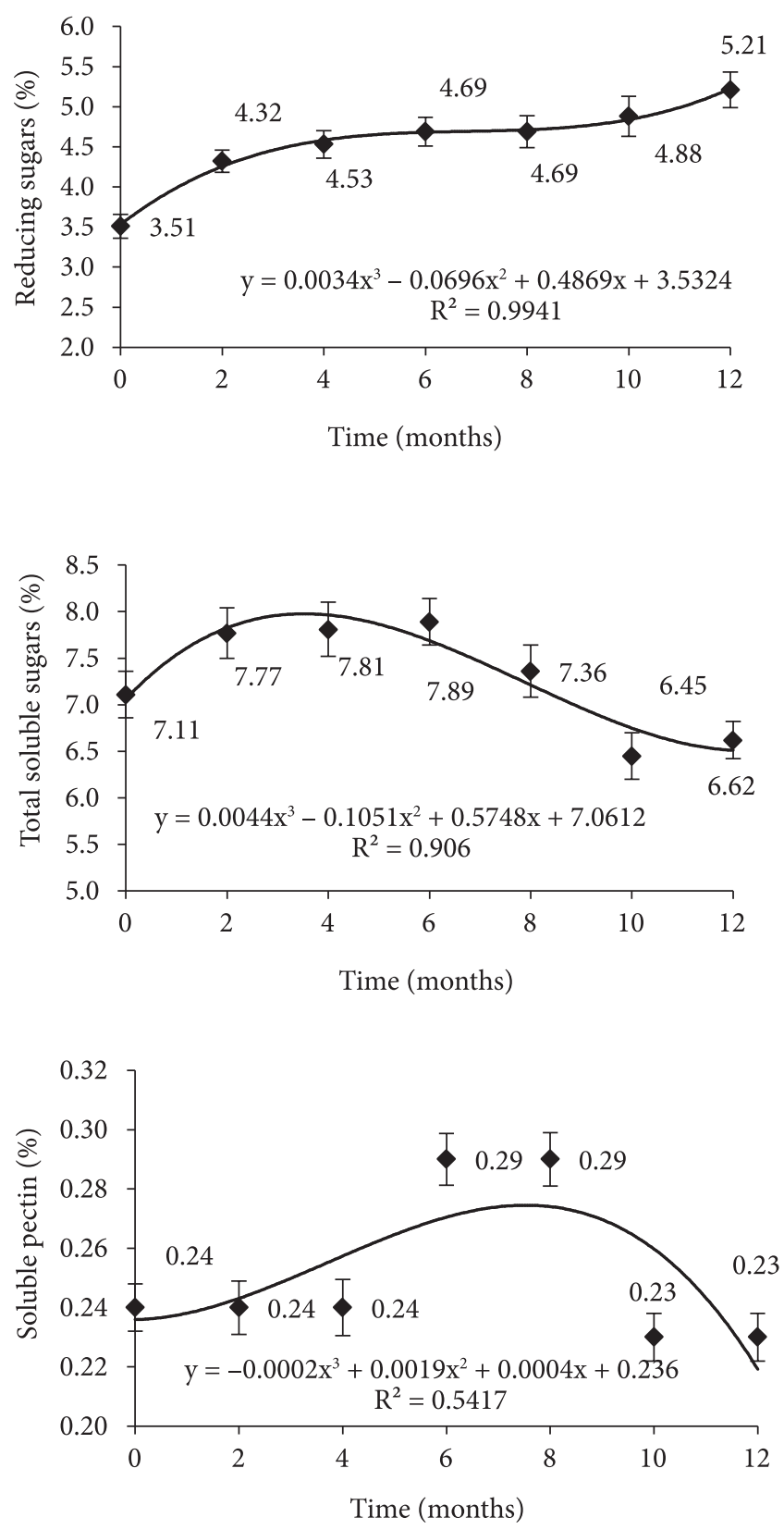

The levels of total sugars, reducing sugars, sucrose, soluble solids, and total and soluble pectin were also influenced by storage time $(\mathrm{p}<0.05)$. Figure 2 shows that among the total soluble sugars, frozen araça pulp showed lower sucrose than reducing sugars levels. During storage, sucrose may have been hydrated and undergone inversion of its molecule into glucose and fructose, which was induced by the low $\mathrm{pH}$ of the medium (Figure 3 ). In acid medium $(\mathrm{pH}<7.0)$, sucrose undergoes reverse reaction forming equal amounts of glucose and fructose (CHEN; CHOU, 1993). Pina et al. (2003) and Torrezan (1996) also observed the inversion of sucrose during storage of mango chunks at room temperature $\left(28^{\circ} \mathrm{C}\right)$ and guava pulp preserved by combined methods, respectively.
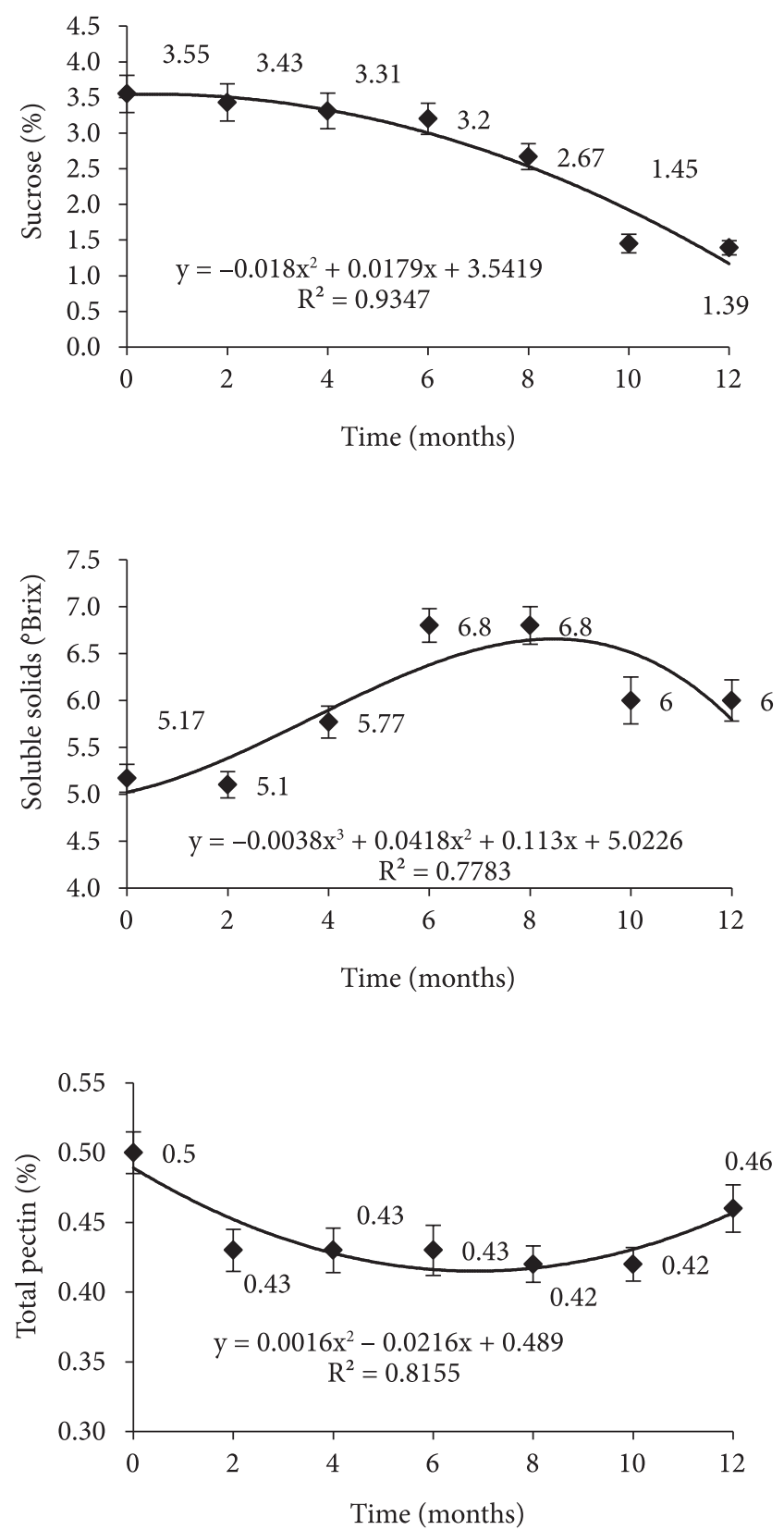

Figure 2. Average contents of total sugars (\%), reducing sugars (\%), sucrose (\%), and soluble solids ( ${ }^{\circ}$ Brix) present in the frozen araça pulp $\left(-18^{\circ} \mathrm{C}\right)$ during 12 months of storage. 
According to Damiani et al. (2011), fresh araçá pulp showed $9.99 \%$ of total soluble sugars, of which $5.91 \%$ was reducing sugars and $3.87 \%$ sucrose. The reduction in the total soluble sugars in relation to the fresh frozen pulp may have been due to the caramelization process during thermal processing, fruit ripening stage, and climatic characteristics.

The content of soluble solids tended to increase as a result of moisture loss during storage, and the levels of total and soluble pectin, at the end of 12 months, changed very little compared to the beginning of the storage period.

The $\mathrm{pH}$ value and the contents of citric, malic, tartaric, and acetic acid were influenced by the storage time $(\mathrm{p}<0.05)$ (Figure 3).

During storage, there was a reduction of $39.52 \%$ in the $\mathrm{pH}$ value, result also observed by Brunini, Oliveira and Varanda (2003) for guava pulp frozen at $-20^{\circ} \mathrm{C}$ for 22 weeks.

In the freezing process, according to Damodaran, Parkin and Fennema (2010), the unfrozen phase, i.e., liquid phase that concentrates non-aqueous compounds (carbohydrates, proteins, lipids, and organic acids among others) undergoes significant changes promoting an increase or a decrease in parameters such as $\mathrm{pH}$, titratable acidity, and ionic strength depending on the chemical composition of the product.

The reduction in $\mathrm{pH}$ values may be justified by fungi present in the frozen araça pulp, which may have consumed soluble sugars through glycolytic pathway, producing organic acids other than those identified in this research. Fruits are very
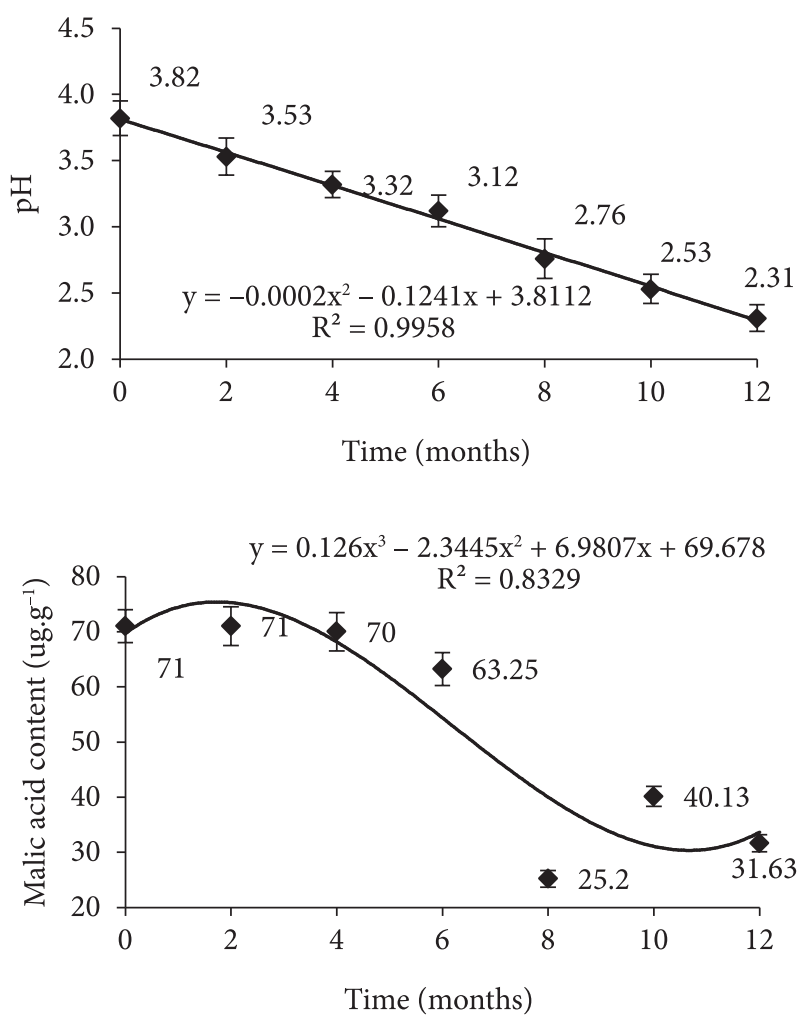

susceptible to the attack of fungi due to their high sugar content. Some fungi such as Saccharomyces bayanus, S. cerevisiae, Saccharomyces sp, Schizosaccharomyces pombe, and S. octosporus are commonly found in frozen pulp (TRINDADE et al., 2002). Saccharomyces and Schizosaccharomyces can be introduced into fruit pulp during processing due to the different maturation stages, in which ripe fruits may have higher concentrations of these species, and they may also be present in the equipment in the form of spores, even after cleaning (KURTZMAN; FELL, 1998).

The presence of filamentous yeasts and molds were detected from the second month of storage (absent at time zero to $2 \times 10^{3} \mathrm{CFU}_{\mathrm{g}}{ }^{-1}$ at 12 months). After this period, the amount reduced to $1 \times 10^{2} \mathrm{CFU} \cdot \mathrm{g}^{-1}$ in the $4^{\text {th }}$ month and remained constant in the remainder of the storage period $\left(1 \times 10^{-1} \mathrm{CFU} \cdot \mathrm{g}^{-1}\right)$. This indicates the presence of heat-resistant spores, followed by inhibition by reducing the $\mathrm{pH}$ of the medium (3.1) after six months of storage. Heat-resistant fungal spores not only support temperatures used in the thermal processing of juices and fruit products (KOTZEKIDOU, 1997), but also are activated by heat (BEUCHAT, 1986), leading to enhanced germination and growth in the final product (MURDOCK; HATCHER, 1978). The presence of organic acids can also promote thermal resistance of these microorganisms (SPLITTSTOESSER; SPLITTSTOESSER, 1977). The heatresistant filamentous fungi species most frequently involved are Byssochlamys nivea, Byssochlamys fulva, Neosartorya fischeri, and Talaromyces flavus (MAGGI et al., 1994; SPLITTSTOESSER; CHUREY, 1991; TOURNAS, 1994).
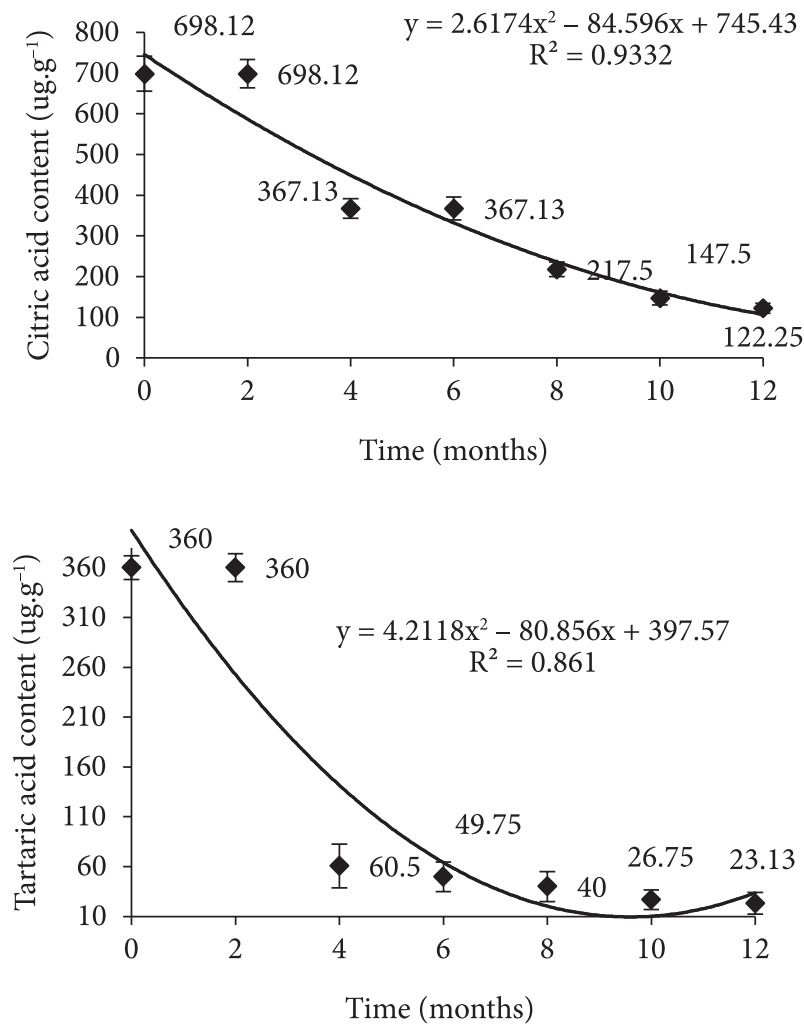

Figure 3. Average values for $\mathrm{pH}(\%)$, ascorbic acid $\left(\mu \mathrm{g} \cdot \mathrm{g}^{-1}\right)$, malic acid $\left(\mu \mathrm{g} \cdot \mathrm{g}^{-1}\right)$, taratric acid $\left(\mu \mathrm{g} \cdot \mathrm{g}^{-1}\right)$, and citric acid $\left(\mu \mathrm{g} \cdot \mathrm{g}^{-1}\right)$ in frozen araça pulp $\left(-18^{\circ} \mathrm{C}\right)$ during 12 months of storage. 
Brazilian law establishes limits for the presence of filamentous fungi and/or yeasts in fruit pulp submitted to heat treatment of $2 \times 10^{3} \mathrm{CFU}_{\mathrm{g}}{ }^{-1}$ (BRASIL, 2000). However, the presence of these organisms can cause physical, chemical, and sensory changes in the product, even when microbiologically stable. The presence of Salmonella sp. and total $\left(35^{\circ} \mathrm{C}\right)$ and thermo-tolerant coliforms $\left(45^{\circ} \mathrm{C}\right)$ was not detected, proving the efficiency of good manufacturing practices during the processing of frozen araça pulp.

The contents of organic acids were reduced, possibly due to their consumption in the metabolism of fungi and/or yeasts. The citric acid concentration was higher during the entire storage period due to its incorporation to reduce the pulp $\mathrm{pH}$ during processing.

According to Damiani et al. (2011), fresh araça pulp had $881.25 \mu \mathrm{g} . \mathrm{g}^{-1}$ citric acid, $761.3 \mu \mathrm{g} . \mathrm{g}^{-1}$ malic acid, $296.3 \mu \mathrm{g} . \mathrm{g}^{-1}$ tartaric acid, and $142.5 \mu \mathrm{g} . \mathrm{g}^{-1}$ ascorbic acid. The reduction in the levels of organic acids in relation to those of fresh fruit can be explained mainly by the thermal processing applied to araça pulp.

The presence of ascorbic acid in frozen araça pulp was not observed. Its loss in relation to the fresh fruit was described by Damiani et al. (2011), which could be attributed to differences in the quality of the raw-material because the fruits were harvested from their own crops and thus they could be at different maturation stages, in addition to the time spent between processing and freezing (CIABOTTI; BRAGA; MATA, 2000 ) and the incorporation of air during the processing steps favoring aerobic degradation reactions by oxidation (LIMA; MÉLO; LIMA, 2000) or even the thermal degradation during blanching and pasteurization (MAIA et al., 2007).

The antioxidant capacity and phenolic compounds were also affected by the storage time ( $\mathrm{p}<0.05)$, as shown in Figure 4 .
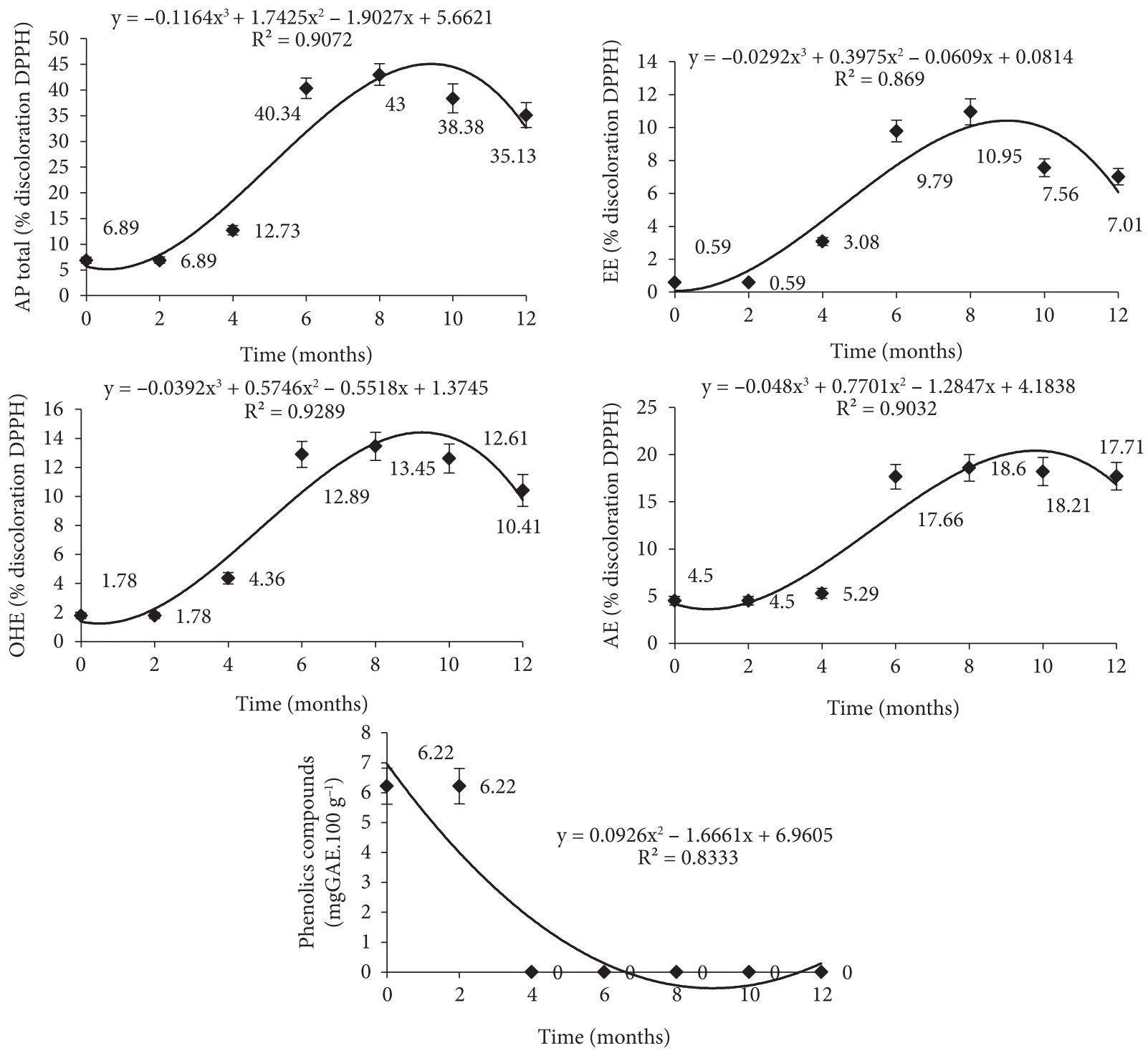

Figure 4. Total antioxidant potential (AP), ethereal extract (EE), ethanol extract (OHE), and aqueous extract (AE), expressed as \% of decolorization of the DPPH radical, and the phenolic compounds in the total extract $\left(\mathrm{mg} \mathrm{GAE}^{\star} .100 \mathrm{~g}^{-1}\right)$ in the frozen araça pulp $\left(-18^{\circ} \mathrm{C}\right)$ during $12 \mathrm{months}$ of storage. ${ }^{*} \mathrm{GAE}$ : gallic acid equivalent; Standard BHT $0.05 \mathrm{mg} \cdot \mathrm{mL}^{-1}=96.27 \%$ and $0.1 \mathrm{mg} \cdot \mathrm{mL}^{-1}=100 \%$. 
The increased antioxidant capacity during the storage of frozen araça pulp can be justified by the loss of moisture (Figure 1) observed between the second and fourth month of storage. Patthamakanokporn et al. (2008) studied guava extracts stored at $5{ }^{\circ} \mathrm{C}$ and also observed a significant increase in the antioxidant activity, from 120 to $190 \%$, during three months of storage. Moreover, during freezing, compounds may be affected by $\mathrm{pH}$ and acidity changes contributing to the increase in antioxidant activity since ionizable hydrogens present in the sample will react with DPPH resulting in increased discoloration of the radical.

According to Damiani et al. (2011), in fresh fruit pulp, the DPPH reduction values were $12.75 \%$ (total), of which $6.52 \%$ was found in the ether extract, $0.30 \%$ in the alcoholic extract, and $5.93 \%$ in the aqueous extract. Lower levels were observed in frozen araça pulp (zero time) in the present study, possibly due to a reaction with oxygen (oxidation) during the stage of fruit pulping and the high temperature used in pasteurization.

Phenolic compounds remained in the frozen pulp up to the second month of storage (alcoholic extract) and were not detected after this period. In the aqueous extract, these compounds were not detected in the processed product. Patthamakanokporn et al. (2008) also found 69\% reduction in phenolic compounds in homogeneous guava extract stored for 3 months $\left(-20^{\circ} \mathrm{C}\right)$.
In the fresh fruit pulp evaluated by Damiani et al. (2011), the amount of phenolic compounds was $113 \mathrm{mg} \mathrm{GAE}$ (aqueous extract). The reduction of $100 \%$ in the content of phenolic compounds in frozen araça pulp may have possibly occurred due to reaction with oxygen (oxidation) during processing. The antioxidant activity of phenolic compounds depends on factors such as oxidation, glycosylation degree, and concentration (VILJANEN; KIVIKARI; HEINONEN, 2004). According to Hassimotto, Genovese and Lajolo (2005), the correlation between phenolic compounds and antioxidant activity of a product is very small $\left(\mathrm{R}^{2}<0.1\right)$, mainly due to differences in the phenolic composition of plant extracts and the variation in responses of different phenolic compounds to Folin-Ciocalteau reagent (KÄHKÖNEN et al., 1999).

The color parameters were also influenced by the storage time $(\mathrm{p}<0.05)$, as shown in Figure 5. $\mathrm{L}^{*}$ value and $\mathrm{a}^{*}$ and $\mathrm{b}^{*}$ coordinates indicated that there was a slight variation in the color of araça pulp during the 12 months of storage, which are less likely to become dark indicating the efficiency of the pasteurization process in enzyme inactivation and the addition of citric acid as acidulant.

In the fresh pulp, these parameters showed values of 52.58 for $\mathrm{L}^{*}, 10.7$ for $\mathrm{a}^{*}$ and 28.64 for $\mathrm{b}^{*}$ (DAMIANI et al., 2011). The reduction of these values in the frozen pulp is justified by the processing since frozen pulp was submitted to heat treatment and incorporation of oxygen, leading to degradation of pigments such as chlorophyll and carotenoids.
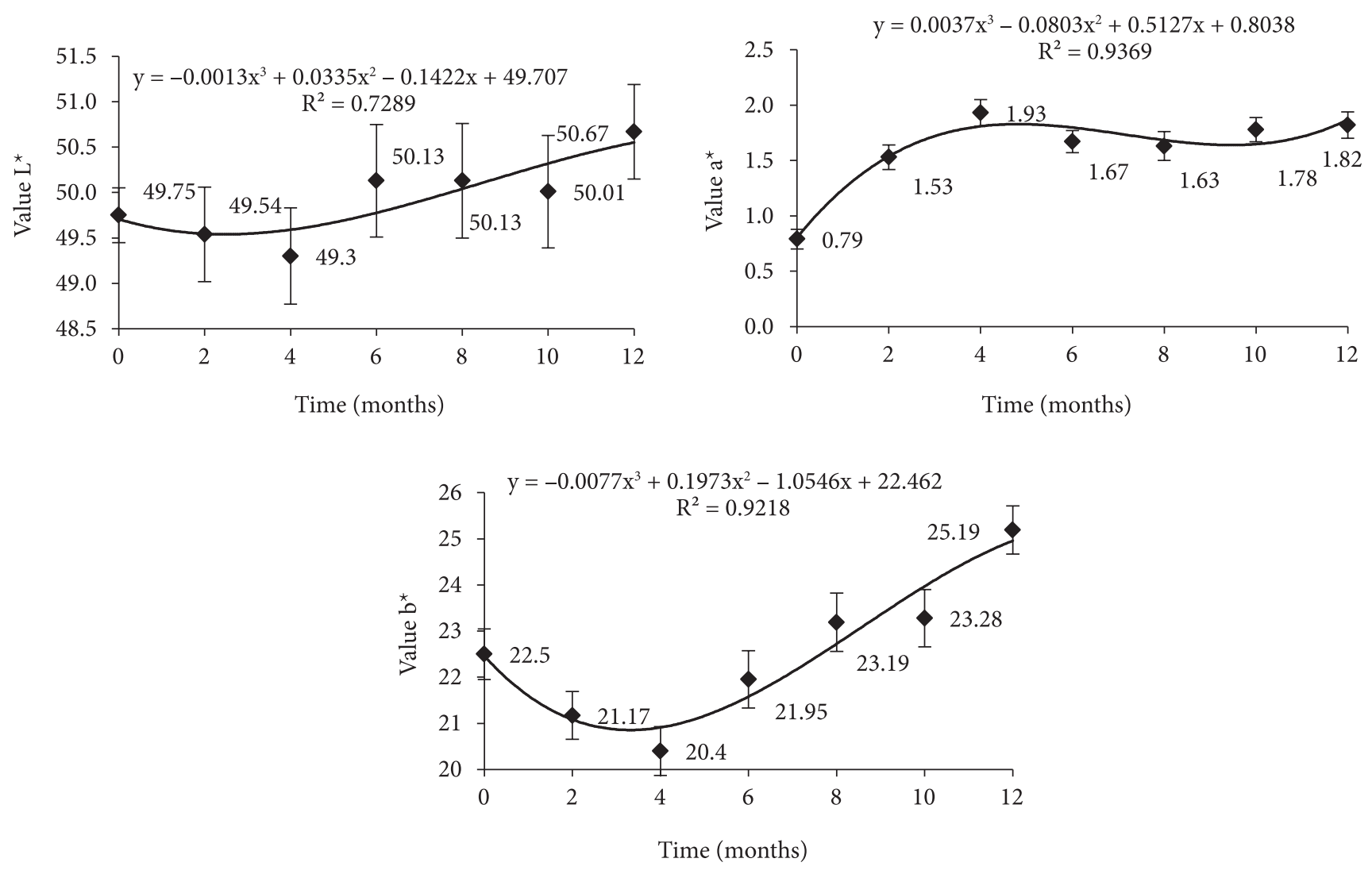

Figure 5. Color parameters $\left(\mathrm{L}^{\star}, \mathrm{a}^{\star}\right.$ and $\left.\mathrm{b}^{\star}\right)$ of frozen araça pulp $\left(-18^{\circ} \mathrm{C}\right)$ during 12 months of storage. 


\section{Conclusions}

With the addition of citric acid, frozen araça pulp can be stored for a period of 12 months at $-18{ }^{\circ} \mathrm{C}$ with changes in the physicochemical parameters without affecting the microbiological quality, as recommended by standards of Brazilian legislation.

\section{Acknowledgements}

This study was financially supported by CNPq, CAPES, and FAPEMIG.

\section{References}

AgOstini-COSTA, T. S.; ABREU, L. N.; ROSSETTI, A. G. Efeito do congelamento e do tempo de estocagem da polpa de acerola sobre o teor de carotenóides. Revista Brasileira de Fruticultura, v. 25, n. 1, p. 56-58, 2003. http://dx.doi.org/10.1590/S010029452003000100017

ALMEIDA, S. P. Cerrado: aproveitamento alimentar. Planaltina: Embrapa, 1998.

ASSOCIATION OF OFFICIAL ANALYTICAL CHEMISTS - AOAC. Official Methods of Analysis of Association of Official Analytical Chemists. Arlington: Ed. Helrich, 1997. 1850 p.

BAZIMARAKENGA, B.; SIMARD, R. R.;LEUROX, G. D. Determination of organic acids in oil extracts by ion chromatography. Soil Biology and Biochemistry, v. 27, p. 349-356, 1995. http://dx.doi. org/10.1016/0038-0717(94)00178-4

BEUCHAT, L. R. Extraordinary heat resistance of Talaromyces flavus and Neosartorya fischeri ascosporos in fruit products. Journal of Food Science, v. 51, n. 6, p. 1506-1510, 1986. http://dx.doi. org/10.1111/j.1365-2621.1986.tb13846.x

BITTER, V.; MUIR, H. M. A modified uronic acid carbazole reaction. Analysis Biochemistry, v. 4, n. 4, p. 330-334, 1962. http://dx.doi. org/10.1016/0003-2697(62)90095-7

BRAND-WILLIAMS, W.; CUVELIER, M. E.; BERSET, C. Use of a free radical method to evaluate antioxidant activity. LWT - Food Science and Technolology, v. 28, n. 1, p. 25-30, 1995.

BORGUINI, R. G.; TORRES, E. F. S. Tomatoes and tomato products as dietary sources of antioxidants. Food Reviews International, v. 25, p. 313-325, 2009. http://dx.doi.org/10.1080/87559120903155859

BRASIL. Ministério da Agricultura, Pecuária e Abastecimento. Instrução Normativa $n^{\circ} 1$, de 07 de janeiro de 2000. Regulamento técnico geral para fixação dos padrões de identidade e qualidade para polpa de fruta. Diário Oficial da República Federativa do Brasil, Brasília, DF, 10 jan. 2000. Seção 1, p. 54.

BRUNINI, M. A.; OLIVEIRA, A. L.; VARANDA, D. B. Avaliação da qualidade de polpa de goiaba 'Paluma' armazenada a $-20{ }^{\circ} \mathrm{C}$. Revista Brasileira de Fruticultura, v. 25, n. 3, p. 394-396, 2003. http://dx.doi.org/10.1590/S0100-29452003000300008

BUENO, S. M. et al. Avaliação da qualidade de polpas de frutas congeladas. Revista do Instituto Adolfo Lutz, v. 62, n. 2, p. 121 $126,2002$.

Cheftel, J. C.; CHEFTEL, H.; BESANÇON, P. Metodos de conservation. In: CHEFTEL, J. C.; CHEFTEL, H.; BESANÇON, P. (Eds.). Introduction a la bioquímica y tecnología de los alimentos. Zaragoza: Acribia, 1989. cap. 7, p. 173-299.
CHEN, J. C. P.; CHOU, C. Cane Sugar Handbook - A manual for cane sugar manufacturers and their chemists. 12nd ed. New York: John Wiley \& Sons, 1993.

CIABOTTI, E. D.; BRAGA, M. E. D.; MATA, M. E. R. M. C. Alterações das características físico-químicas da polpa de maracujá-amarelo submetido a diferentes técnicas de congelamento inicial. Revista Brasileira de Produtos Agroindustriais, v. 2, n. 1, p. 51-60, 2000.

DAMIANI, C. et al. Characterization of fruits from the savanna: Araça (Psidium guinnensis Sw.) and Marolo (Annona crassiflora Mart.). Ciência e Tecnologia de Alimentos, v. 31, n. 3, p. 723-729, 2011. http://dx.doi.org/10.1590/S0101-20612011000300026

DAMODARAN, S.; PARKIN, K. L.; FENNEMA, O. R. Química de alimentos de Fennema. 4. ed. Porto Alegre: Artmed, 2010.

DUBOIS, M. et al. Colorimetric method for determination of sugars and related substances. Analytical Chemistry, v. 28, n. 3, p. 350-355, 1956. http://dx.doi.org/10.1021/ac60111a017

FERREIRA, D. F. Análises estatísticas por meio do SISVAR para Windows versão 4.0, São Carlos, S.P, 2000. In: REUNIÃO ANUAL DA REGIÃO BRASILEIRA DA SOCIEDADE INTERNACIONAL DE BIOMETRIA, 2000, São Carlos. Anais... São Carlos: EdUFSCar, 2000. p. 235.

FRANCO, G. Tabela de composição química dos alimentos. 9. ed. São Paulo: Atheneu, 1999.

GENOVESE, M. I. et al. Determinação do conteúdo de fenólicos totais em frutas. Revista Brasileira de Ciências Farmacêuticas, v. 39, n. 3, p. 167-169, 2003.

HASSimotTO, N. M. A.; GENOVESE, M. I.; LAJOLO, F. M. Antioxidant activity of dietary fruits, vegetables, and commercial frozen fruit pulps. Journal of Agricultural and Food Chemistry, v. 53, n. 8, p. 2928-2935, 2005. PMid:15826041. http://dx.doi. org/10.1021/jf047894h

INTERNATIONAL COMMISSION ON MICROBIOLOGICAL SPECIFICATIONS FOR FOODS - ICMSF. Microrganisms in food. 2nd ed. Toronto: University of Toronto, 1983.

KÄHKÖNEN, M. P. et al. Antioxidant activity of plant extracts containing phenolic compounds. Journal of Agricultural and Food Chemistry, v. 47, p. 3954-3962, 1999. PMid:10552749. http://dx.doi. org/10.1021/jf9901461

KOTZEKIDOU, P. Heat of Byssochlamys nivea, byssochlamys fulva and Neoartorya fischeri isolated from canned tomato paste. Journal of Food Science, v. 62, n. 2, p. 410-412, 437, 1997.

KURTZMAN, C. P.; FELL, J. The yeasts - a taxonomic study. 4th ed. Amsterdam: Elsevier Science B.V., 1998.

LIMA, V. L. A. G.; MÉLO, E. A.; LIMA, L. S. Avaliação da qualidade de suco de laranja industrializado. Boletim do CEPPA, v. 18, n. 1, p. 95-104, 2000.

MAGGI, A. et al. Trattamenti ad alta pressione di ascospore di muffe termoresistenti e di patulina in nettare di albicocca e in acqua. Indústria Conserve, v. 69, n. 1, p. 26-29, 1994.

MAIA, G. A. et al. Efeito do processamento sobre componentes do suco de acerola. Ciência e Tecnologia de Alimentos, v. 27, n. 1, p. 130134, 2007. http://dx.doi.org/10.1590/S0101-20612007000100023

MANICA, I. Frutas nativas, silvestres e exóticas 1: Técnicas de produção e mercado: abiu, amora-preta, araçá, bacuri, biriba, carambola, cereja-do-rio-grande, jabuticaba. Porto Alegre: Cinco Continentes, 2000. PMid:14647663.

MURDOCK, D. I.; HATCHER, W. S. A simple method to screen fruit juices and concentrates for heat resistant mold. Journal of Food Protection, v. 41, p. 54-256, 1978. 
PATTHAMAKANOKPORN, O. et al. Changes of antioxidant activity and total phenolic compounds during storage of selected fruits. Journal of Food Composition and Analysis, v. 21, n. 3, p. 241-248, 2008. http://dx.doi.org/10.1016/j.jfca.2007.10.002

PINA, M. G. M. et al. Processamento e conservação de manga por métodos combinados. Revista Brasileira de Fruticultura, v. 25 , n. 1, p. 63-66, 2003. http://dx.doi.org/10.1590/S010029452003000100019

SILVA, V. K. L. et al. Estabilidade da polpa do bacuri (Platonia insignis Mart.) congelada por 12 meses. Revista Ciência e Agrotecnologia, v. 34, n. 5, p. 1293-1300, 2010. http://dx.doi.org/10.1590/S141370542010000500030

SILVA, F. A. et al. Exsudação de ácidos orgânicos em rizosfera de plantas daninhas. Planta Daninha, v. 19, n. 2, p. 193-196, 2001. http://dx.doi.org/10.1590/S0100-83582001000200006

SILVA, M. R.; SANTOS JÚNIOR, R. T. O.; FERREIRA, C. C. C. Estabilidade da vitamina $\mathrm{C}$ em cagaita in natura e durante a estocagem da polpa e refresco. Pesquisa Agropecuária Tropical, v. 38, n. 1, p. 53-58, 2008.

SPLITTSTOESSER, D. F.; CHUREY, J. J. Reduction of heat resistance of Neosartorya fischeri ascospores by sulfur dioxide. Journal of Food Science, v. 56, n. 3, p. 876-877, 1991. http://dx.doi. org/10.1111/j.1365-2621.1977.tb12579.x

SPLITTSTOESSER, D. F.; SPLITTSTOESSER, M. C. Ascospores of Byssochlamys fulva compared with those of a heat- resistant Aspergillus. Journal of Food Science, v. 42, n. 3, p. 685-688, 1977. http://dx.doi.org/10.1111/j.1365-2621.1991.tb05408.x
TRINDADE, R. C. et al. Yeasts associated with fresh and frozen pulps of Brazilian tropical fruits. Systematic and Applied Microbiology, v. 25, p. 294-300, 2002. PMid:12353886. http:// dx.doi.org/10.1078/0723-2020-00089

TOURNAS, V. Heat-resistant fungi of importance to the food and beverage industry. Critical Reviews in Microbiology, v. 20, n. 4 , p. 243-263, 1994. PMid:7857517. http://dx.doi. org/10.3109/10408419409113558

TORREZAN, R. Preservação de polpa de goiaba por métodos combinados. 1996. 211 f. Dissertação (Mestrado em Tecnologia de Alimentos)-Faculdade de Engenharia de Alimentos, Universidade Estadual de Campinas, Campinas, 1996.

VILJANEN, K.; KIVIKARI, R.; HEINONEN, M. Protein - lipid interactions during liposome oxidation with added anthocyanin and other phenolic compounds. Journal of Agriculture and Food Chemistry, v. 52, p. 1104-1111, 2004. PMid:14995106. http://dx.doi. org/10.1021/jf034785e

WILSON, E. D.; SANTOS, A. C.; VIEIRA, E. C. Energia. In: DUTRA OLIVEIRA, J. E.; SANTOS, A. C.; WILSON, E. D. Nutrição básica. São Paulo: Savier, 1982.

YAMASHITA, F. et al. Produtos de acerola: estudo da estabilidade de vitamina C. Ciência e Tecnologia de Alimentos, v. 23, n. 1, p. 9294, 2003. http://dx.doi.org/10.1590/S0101-20612003000100019

ZIELISKI, H.; KOZOWSKA, H. Antoixidant activity and total phenolics in selected cereal graims and their different morphological fractions. Journal Agricultural Food Chemistry, v. 48, p. 20082016, 2000. http://dx.doi.org/10.1021/jf990619o 